\title{
Treatments for reversing warfarin anticoagulation in patients with acute intracranial hemorrhage: a structured literature review
}

\author{
Brett F Bechtel', Timothy C Nunez ${ }^{1}$, Jennifer A Lyon ${ }^{3}$, Bryan A Cotton ${ }^{4}$ and Tyler W Barrett ${ }^{1 *}$
}

\begin{abstract}
Study objective: The acute management of patients on warfarin with spontaneous or traumatic intracranial hemorrhage continues to be debated in the medical literature. The objective of this paper was to conduct a structured review of the medical literature and summarize the advantages and risks of the available treatment options for reversing warfarin anticoagulation in patients who present to the emergency department with acute intracranial hemorrhage.

Methods: A structured literature search and review of articles relevant to intracranial hemorrhage and warfarin and treatment in the emergency department was performed. Databases for PubMed, CINAHL, and Cochrane EBM Reviews were electronically searched using keywords covering the concepts of anticoagulation drugs, intracranial hemorrhage $(\mathrm{ICH})$, and treatment. The results generated by the search were limited to English- language articles and reviewed for relevance to our topic. The multiple database searches revealed 586 papers for review for possible inclusion. The final consensus of our comprehensive search strategy was a total of 23 original studies for inclusion in our review.

Results: Warfarin not only increases the risk of but also the severity of $\mathrm{ICH}$ by causing hematoma expansion. Prothrombin complex concentrate is statistically significantly faster at correcting the INR compared to fresh frozen plasma transfusions. Recombinant factor VIla appears to rapidly reverse warfarin's effect on INR; however, this treatment is not FDA-approved and is associated with a 5\% thromboembolic event rate. Slow intravenous dosing of vitamin $\mathrm{K}$ is recommended in patients with $\mathrm{ICH}$. The 30-day risk for ischemic stroke after discontinuation of warfarin therapy was 3-5\%. The risks of not reversing the anticoagulation in $\mathrm{ICH}$ generally outweigh the risk of thrombosis in the acute setting.

Conclusions: Increasing numbers of patients are on anticoagulation including warfarin. There is no uniform standard for reversing warfarin in intracranial hemorrhage. Intravenous vitamin $\mathrm{K}$ in addition to fresh frozen plasma or prothrombin complex concentrate is recommended be used to reverse warfarin-associated intracranial hemorrhage. No mortality benefit for one treatment regimen over another has been shown. Emergency physicians should know their hospital's available warfarin reversal options and be comfortable administering these treatments to critically ill patients.
\end{abstract}

\section{Introduction}

Outpatient prescriptions for warfarin increased $45 \%$ to 31 million in the United States during the period of 19982004 [1]. Warfarin usage will increase with the rising prevalence of diseases such as atrial fibrillation and the aging of the population [2]. There are more than 1 million

\footnotetext{
* Correspondence: Tyler.barrett@vanderbilt.edu

'Department of Emergency Medicine, Vanderbilt University Medical Center, Nashville, TN, USA

Full list of author information is available at the end of the article
}

emergency department (ED) visits annually for traumatic brain injury (TBI) in the US [3]. The use of warfarin increases a patient's risk for spontaneous intracranial hemorrhage and overall mortality. The incidence of spontaneous intracranial hemorrhage $(\mathrm{ICH})$ is 7-10 times higher among patients taking warfarin compared to those not on anticoagulation [4]. Patients taking warfarin therapy account for $8-14 \%$ of all ICH $[4,5]$, and ICH occurs 8-10 times more frequently in individuals on warfarin $[4,6]$. The annual risk of $\mathrm{ICH}$ in patients treated with

\section{SpringerOpen ${ }^{\circ}$}

(C) 2011 Bechtel et al; licensee Springer. This is an Open Access article distributed under the terms of the Creative Commons Attribution License (http://creativecommons.org/licenses/by/2.0), which permits unrestricted use, distribution, and reproduction in any medium, provided the original work is properly cited. 
warfarin has been estimated to be between $0.3-2.0 \%$ [7-10]. ICH is the most lethal form of CVA with 30-day mortality rates estimated at $30-55 \%[8,9,11]$, while those on warfarin have a higher risk of death at 30 days of 43$60 \%[9,11,12]$. Alarmingly, between $50-90 \%$ of all $\mathrm{ICH}$ occurs while the INR is within the target range [7].

Different therapies such as fresh frozen plasma (FFP), vitamin K, prothrombin complex concentrates (PCC), which contain factors II, VII, IX, and X, and recombinant activated factor VII (rfVIIa) have all been used as ways to treat $\mathrm{ICH}$ in this high-risk population, either alone or in combination. Acute interventions that minimize or arrest ongoing bleeding and hematoma size are likely to be critical for improving outcomes $[4,13]$. This makes the role of the ED physician paramount in diagnosis and management of warfarin-associated $\mathrm{ICH}$ in a timely manner.

The objective of this systematic review is to summarize the medical literature regarding the benefits and risks of the available treatment options to reverse warfarin anticoagulation in patients with acute $\mathrm{ICH}$.

\section{Materials and methods}

\section{Study design and data sources}

We conducted a comprehensive literature search of the databases MEDLINE ${ }^{\circledR}$ (via PubMed ${ }^{\circledR} ; 1950-$ ) through 2009 using a combination of Medical Subject Terms $\left(\mathrm{MESH}^{\mathbb{B}}\right)$ and keywords covering the concepts of anticoagulation drugs, intracranial hemorrhage (ICH), and treatment. A sample search strategy was "(Anticoagulants[mh] OR Anticoagulants [Pharmacological Action]) AND Intracranial Hemorrhages[mh] AND therapeutics[mh] AND English[la]," which yielded 1,082 citations as of 29 December 2009 . We limited the search to study designs that included the following: clinical trial, meta-analysis, and practice guideline, randomized controlled trial. This search resulted in a total of 382 (/29 December 2009) abstracts.

Two independent reviewers (BFB, TCN) examined the abstracts and made separate recommendations for inclusion. A third reviewer (TWB) adjudicated any disagreements between the two primary reviewers. This review yielded 37 articles that were selected for full-text evaluation based on the following inclusion/exclusion criteria:

1. Patient taking an anticoagulant drug, with preference for warfarin

2. Patient diagnosed with intracranial hemorrhage

3. Article contains information on treatment/management of $\mathrm{ICH}$

4. Article contains raw data and was original research study

From these, 14 additional articles were hand selected from the papers' references for inclusion. This yielded a total of 51 studies, of which 30 were reviews. The reviews were excluded, resulting in 21 original studies for evaluation.

We additionally searched the Cochrane Database of Systematic Reviews (via OVID ${ }^{\circledR}$ ) and the Cumulative Index of Nursing and Allied Health Literature $\left(\right.$ CINAHL $^{\circledR}$ Via EBSCOhost ${ }^{\circledR}$ ) for relevant reviews and articles as of December 2009. We identified no relevant reviews in the Cochrane Database. A search of CINAHL-using ((MH "Intracranial Hemorrhage+") or (MH "Cerebral Hemorrhage+")) AND ((MH "Anticoagulants+") or (MH "Heparin+") or (MH "Warfarin"))-limited to English language, Clinical Trials, Journal Articles, Practice Guidelines, Research, and Systematic Reviews, retrieved 204 abstracts of which 31 were selected. Three of the 31 were eliminated as duplicates to the PubMed search, yielding 28 that were added to the PubMed results for further examination. Two independent reviewers (BFB, TWB) examined the 28 abstracts and chose two for ultimate inclusion in the paper based on the above inclusion/exclusion criteria. The final consensus of our comprehensive search strategy was a total of 23 original studies for inclusion in our review. Two reviewers assessed the quality of evidence for each of these 23 manuscripts using the GRADE system that classifies studies from high to very low based on study design and internal validity measures [14].

\section{Results}

The available literature consists primarily of small case series and retrospective cohort studies with the majority classified as low, thus limiting the strength of findings [14]. Variation in federal regulatory drug agency approvals also impacts reporting as PCC is approved and considered a standard reversal treatment in most nations [6]. The US Federal Drug Agency, however, has yet to approve a PCC formulation that is sufficient for warfarin reversal, thus leaving thawed plasma as the only available clotting factor option for rapid reversal.

This review focuses on warfarin-associated intracranial hemorrhage (WAICH) from spontaneous causes; however, the acute management of WAICH appears to include the same treatments regardless of whether the $\mathrm{ICH}$ was spontaneous or traumatic. However, the literature on traumatic WAICH is limited because of small sample sizes (Table 1) [15-18].

\section{Rationale for rapid correction of anticoagulation in the emergency department}

Warfarin not only increases the risk of but also the severity of ICH by causing hematoma expansion [10]. Hematoma progression was found to occur in nearly $40 \%$ of ICH patients with $\mathrm{ICH}$ in the first few hours following symptom onset [4]. Hematoma enlargement 
Table 1 Studies investigating reversal of warfarin anticoagulation in traumatic intracranial hemorrhage

\begin{tabular}{|c|c|c|c|c|c|}
\hline Author & Study type & Patient population & Intervention & Result & $\begin{array}{l}\text { Grade } \\
{[14]}\end{array}$ \\
\hline $\begin{array}{l}\text { Bartal et al. } \\
2007\end{array}$ & Prospective & $\begin{array}{l}7 \text { patients on warfarin } \\
\text { with traumatic ICH }\end{array}$ & $\begin{array}{l}\text { All received vitamin } \mathrm{K} \text { and } 6-12 \text { units of } \\
\text { FFP. INR was still }>1.3 \text { in all, so } 40-90 \\
\mu \mathrm{g} / \mathrm{kg} \text { rfVIlla was given. INR dropped } \\
\text { below } 1.3 \text {, and all underwent } \\
\text { neurosurgery }\end{array}$ & $\begin{array}{l}\text { rfVIla lowered the INR into operable } \\
\text { range in all patients. }\end{array}$ & Low \\
\hline $\begin{array}{l}\text { Baldi et al. } \\
2006\end{array}$ & Prospective & $\begin{array}{l}232 \text { on warfarin or } \\
\text { acenocumarol or with INR } \\
\text { equal or }>2 \text { with } \\
\text { spontaneous or traumatic } \\
\text { ICH }\end{array}$ & $\begin{array}{l}\text { FFP used in } 22 \% \text { of patients, vitamin } \mathrm{K} \text { in } \\
41 \% \text {, } \mathrm{PCC} \text { in } 6 \% \text { and factor VII } \\
\text { concentrate in } 3 \% \text {. Many did not receive } \\
\text { any reversal treatment }\end{array}$ & $\begin{array}{l}\text { No statistical differences were found in } \\
\text { the outcomes of patients with or } \\
\text { without medical therapy }\end{array}$ & Low \\
\hline $\begin{array}{l}\text { Kalina et } \\
\text { al. } 2008\end{array}$ & Prospective & $\begin{array}{l}46 \text { trauma patients on } \\
\text { warfarin with ICH with } \\
\text { INR }>1.5\end{array}$ & $\begin{array}{l}\text { Institution developed protocol for } \\
\text { trauma patients with ICH taking warfarin } \\
\text { with INR }>1.5 \text {. Patients given weight- } \\
\text { based dose of PCC (concentrated II, VII, } \\
\text { IX, X). All given } 5 \mathrm{mg} \text { vitamin } \mathrm{K} \text { as well. } \\
\text { Patients could receive FFP as well in } \\
\text { protocol group }\end{array}$ & $\begin{array}{l}\text { Protocol resulted in increased number of } \\
\text { patients receiving PCC. Protocol patients } \\
\text { had improved times to INR } \\
\text { normalization, patients having reversal of } \\
\text { coagulopathy, and shorter times to } \\
\text { surgery. No difference in ICU days, } \\
\text { hospital days, or mortality. } 2 / 48 \text { that got } \\
\text { PCC had DVT }\end{array}$ & Low \\
\hline $\begin{array}{l}\text { Ivascu et } \\
\text { al. } 2006\end{array}$ & Retrospective & $\begin{array}{l}57 \text { patients with } \\
\text { traumatic WAICH from fall } \\
\text { or MVC }\end{array}$ & $\begin{array}{l}\text { Established and implemented protocol } \\
\text { to treat traumatic WAICH. All } 35 \text { protocol } \\
\text { patients received FFP. Only } 14 / 22 \\
\text { patients in the pre-protocol group } \\
\text { received FFP }\end{array}$ & $\begin{array}{l}\text { Mortality and reversal times of INR were } \\
\text { similar between the protocol instituted } \\
\text { group and the pre-protocol group }\end{array}$ & Low \\
\hline
\end{tabular}

within 6-12 h is commonly seen in patients on warfarin with $\mathrm{ICH}$ [19]. As volume and ventricular extension increase, earlier patient deterioration is observed [20]. Goldstein et al. found that for every 30-min delay in FFP administration, the probability of successful INR reversal within $24 \mathrm{~h}$ decreases by $20 \%$ [21]. Interventions aimed at preventing this growth are paramount as larger hematomas are associated with poorer functional outcomes [13,20].

\section{Administration of prothrombin complex concentrates versus fresh frozen plasma}

Warfarin inhibits the production of vitamin K-dependent clotting factors; therefore, patients with WAICH should have their clotting factors repleted. Treatment options for the repletion of clotting factors include FFP and PCC.

FFP contains all coagulation factors in non-concentrated form. FFP is more universally available at hospitals, especially in the US, compared to PCC. Administration of FFP, a blood product, requires compatibility testing and carries the risk of blood borne infection transmission and transfusion-related acute lung injury (TRALI). FFP is stored frozen, thus requiring at least 15-20 min to thaw [6]. Large FFP volumes (800 to $3,500 \mathrm{~mL}$ ) are often needed to treat serious hemorrhages [22]. This large volume may result in acute decompensated heart failure in patients with atrial fibrillation or cardiac valve disease and ventricular dysfunction. Less common adverse events including allergic reactions are also possible with FFP [6].
PCC contains coagulation factors II, VII, IX, and X, and proteins $C, S$, and $Z$ in concentrated form [6]. European and Australian practice protocols recommend the use of PCC in bleeding emergencies [6]. PCC is not widely available in US hospitals, and, while cheaper than rfVIIa, it is more expensive than FFP. PCC risks include potential thrombotic complications and disseminated intravascular coagulation (DIC) [6]. The optimal PCC dosing is calculated according to patient age, body weight, severity of INR prolongation, and desired level of INR correction with typical dosages of 25 to $50 \mathrm{IU} / \mathrm{kg}$ [19].

Studies have compared the use of PCC and FFP in patients with WAICH, measuring which treatment corrected the INR faster (Table 2). Makris et al. found that PCC outperformed FFP at repleting factors II, VII, IX, and $\mathrm{X}$ [23]. PCC administration normalized the INR, whereas the INR remained elevated in patients given FFP [23]. Fredriksson et al. retrospectively found that PCC worked significantly faster than FFP. The mean INR decreased from 2.83 to 1.22 within $4.8 \mathrm{~h}$ in the ten patients treated with PCC compared with an INR decrease from 2.97 to 1.74 within $7.3 \mathrm{~h}$ in those seven patients receiving FFP [24]. These findings, however, are not surprising as FFP lacks concentrated factors and has an INR of 1.3-1.4.

Cartmill et al. prospectively studied 12 patients with WAICH. They treated six patients with $50 \mu \mathrm{g} / \mathrm{kg}$ intravenous (IV) PCC and $10 \mathrm{mg}$ IV vitamin K. Six matched patients were treated with 4 units of FFP and $10 \mathrm{mg}$ IV vitamin $\mathrm{K}$. The investigators measured the INR at baseline and 15 min after treatment. The PCC group had significantly faster and complete reversal compared to the 
Table 2 Studies investigating PCC versus FFP for anticoagulation reversal in warfarin-associated intracranial hemorrhage

\begin{tabular}{|c|c|c|c|c|c|}
\hline Author & Study type & $\begin{array}{l}\text { Patient } \\
\text { population }\end{array}$ & Intervention & Result & $\begin{array}{l}\text { Grade } \\
{[14]}\end{array}$ \\
\hline $\begin{array}{l}\text { Makris et al. } \\
1997\end{array}$ & Prospective & $\begin{array}{l}16 \text { patients with } \\
\text { WAICH, along } \\
\text { with } 12 \text { "similar } \\
\text { subjects" }\end{array}$ & $\begin{array}{l}\text { Vitamin K } 1-5 \mathrm{mg} \text { IV given to all patients. } \\
16 \text { patients got PCC and } 12 \text { FFP }\end{array}$ & $\begin{array}{l}\text { PCC repleted factors II, VII, IX, and X better } \\
\text { than FFP. In patients given FFP, INR } \\
\text { remained elevated. } 28 / 29 \text { patients given } \\
\text { PCC had INR correction }\end{array}$ & Moderate \\
\hline $\begin{array}{l}\text { Fredriksson } \\
\text { et al. } 1992\end{array}$ & Retrospective & $\begin{array}{l}17 \text { patients with } \\
\text { WAICH }\end{array}$ & $\begin{array}{l}\text { All patients received vitamin } \mathrm{K} 10-20 \mathrm{mg} \text { IV. } \\
\text { Of the } 17 \text { total patients, } 10 \text { received PCC } \\
\text { and } 7 \text { received FFP }\end{array}$ & $\begin{array}{l}\text { PCC significantly decreased the INR from } \\
2.83 \text { to } 1.22 \text { within } 4.8 \mathrm{~h} \text {, compared with a } \\
\text { decrease in INR from } 2.97 \text { to } 1.74 \text { within } \\
7.3 \mathrm{~h} \text { in the FFP group. Signs and } \\
\text { symptoms of ICH progressed more in } \\
\text { those treated with FFP than with PCC }\end{array}$ & Low \\
\hline $\begin{array}{l}\text { Boulis et al. } \\
1999\end{array}$ & $\begin{array}{l}\text { Prospective, } \\
\text { randomized } \\
\text { controlled } \\
\text { trial }\end{array}$ & $\begin{array}{l}13 \text { patients with } \\
\text { WAICH }\end{array}$ & $\begin{array}{l}\text { All patients received vitamin K } 10 \text { mg } \\
\text { subcutaneously. } 8 \text { patients received FFP. } 5 \\
\text { patients received weight-based dosing of } \\
\text { factor IX complex concentrate (FIXCC) in } \\
\text { addition to FFP }\end{array}$ & $\begin{array}{l}\text { Significant differences were found in time } \\
\text { to correction, rate of correction, and } \\
\text { volume of FFP required for correction } \\
\text { between the FFP group }(8.9,2,700 \mathrm{~mL}) \text { and } \\
\text { the FIXCC + FFP group }(2.95,399 \mathrm{~mL})\end{array}$ & Moderate \\
\hline $\begin{array}{l}\text { Cartmill et al. } \\
2000\end{array}$ & Prospective & $\begin{array}{l}12 \text { patients with } \\
\text { spontaneous } \\
\text { WAICH }\end{array}$ & 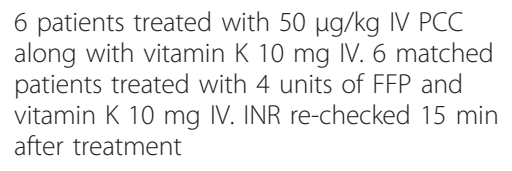 & $\begin{array}{l}\text { PCC group had significantly faster and } \\
\text { complete reversal compared to the FFP } \\
\text { group. Mean post-treatment INRs were } \\
1.32 \text { in PCC group and } 2.3 \text { in FFP group }\end{array}$ & Low \\
\hline $\begin{array}{l}\text { Siddiq et al. } \\
2008\end{array}$ & Retrospective & $\begin{array}{l}19 \text { patients with } \\
\text { diagnosis of } \\
\text { WAICH }\end{array}$ & $\begin{array}{l}10 \text { patients treated with PCC, vitamin K, } \\
\text { and FFP, and } 9 \text { patients treated with FFP } \\
\text { and vitamin } \mathrm{K}\end{array}$ & $\begin{array}{l}\text { PCC along with FFP and vitamin } \mathrm{K} \text { trends } \\
\text { toward faster normalization of INR than } \\
\text { with FFP and vitamin } \mathrm{K} \text { alone }\end{array}$ & Low \\
\hline
\end{tabular}

FFP group. The mean post-treatment INRs in the PCC and FFP groups were 1.32 and 2.3, respectively [25].

Boulis et al. performed a randomized control trial comparing treatment with FFP and FFP + factor IX complex concentrate (FIXCC) in patients with acute ICH. FIXCC, similar to other PCC formulations, contains high concentrations of activated vitamin K-dependent factors (factors II, VII, IX, and X). The study included 13 patients, 8 receiving FFP alone and 5 receiving FFP and FIXCC. All patients received vitamin K 10 mg subcutaneously (SQ). They reported significant differences in time to correction, rate of correction, and volume of FFP required for correction between the FFP group (mean $8.9 \mathrm{~h}, 2,700 \mathrm{cc}$ ) and the FIXCC + FFP group (mean 2.95 h, 399 cc) [22]. Another study retrospectively evaluated ten patients treated with FIXCC + $\mathrm{FFP}+$ vitamin $\mathrm{K}$ and nine patients treated with FFP + vitamin $\mathrm{K}$ alone [26]. FIXCC used along with FFP and vitamin $\mathrm{K}$ trends toward faster normalization of INR than with FFP and vitamin $\mathrm{K}$ alone.

In conclusion, $\mathrm{PCC}$ is statistically significantly faster than FFP at correcting the INR in patients taking warfarin. None of these studies, however, demonstrated a statistically significant clinical outcome difference between those treated with FFP or PCC.

\section{Use of recombinant factor VIla for warfarin reversal in ICH (Table 3)}

Recombinant factor VIIa (rfVIIa) is the cloned activated form of endogenous human hemostatic factor VII. Its original use was for hemophiliac patients. rfVIIa is given as an IV bolus over 2-5 min, with its onset of action being almost immediate and clinically apparent hemostasis observed within $10 \mathrm{~min}$ [27]. However, it is expensive to use, with a 1.2-mg vial costing approximately USD $\$ 1,369$ [27]. There is no risk of blood-borne pathogen transmission, but there is a clinically important risk of thrombotic complications. A systematic review of 35 randomized clinical trials reported arterial and venous thromboembolic rates of $5.5 \%$ and $5.3 \%$, respectively [28]. The half-life of rfVIIa is short unless the dose is increased to $120 \mu \mathrm{g} / \mathrm{kg}$. At this dose, rfVIIa was able to correct INR for periods of $24 \mathrm{~h}$ without signs of systemic coagulation in one study [27].

Bartal et al. in 2007 did a prospective study on seven patients with WAICH. They all received vitamin $\mathrm{K}$ and between 6- 12 units of FFP. The INR was still greater than 1.3 in all, and so $40-90 \mu \mathrm{g} / \mathrm{kg}$ IV rfVIIa was given. This rapidly corrected the INR to below 1.3 [15]. Sorensen et al. evaluated six patients who all received vitamin $\mathrm{K}$, and three were transfused FFP. The patients' INRs remained elevated ( $>1.5$ ), so each patient was given 10$40 \mu \mathrm{g} / \mathrm{kg}$ rfVIIa in preparation for emergent neurosurgery. All six patients' INRs were $\leq 1.5$ within 10 min of rfVIIa administration and underwent neurosurgery [29]. Freeman et al. treated seven patients with $15-90 \mu \mathrm{g} / \mathrm{kg}$ of rfVIIa. All patients but one also received vitamin $\mathrm{K}$ and FFP. They found that an rfVIIa IV bolus rapidly lowered the INR to normalized levels [30]. Brody treated 15 patients with vitamin K $10 \mathrm{mg}$ IV or SQ and FFP. 
Table 3 Studies investigating recombinant factor VIla for anticoagulation reversal in intracranial hemorrhage

\begin{tabular}{|c|c|c|c|c|c|}
\hline Author & Study type & $\begin{array}{l}\text { Patient } \\
\text { population }\end{array}$ & Intervention & Result & $\begin{array}{l}\text { Grade } \\
\text { [14] }\end{array}$ \\
\hline $\begin{array}{l}\text { Bartal et al. } \\
2007\end{array}$ & Prospective & $\begin{array}{l}7 \text { patients on } \\
\text { warfarin with } \\
\text { traumatic ICH }\end{array}$ & $\begin{array}{l}\text { All received vitamin } \mathrm{K} \text { and between } 6-12 \\
\text { units of FFP. INR was still }>1.3 \text { in all and so } \\
40-90 \mu \mathrm{g} / \mathrm{kg} \text { rfVlla was given. INR went } \\
\text { below } 1.3 \text {, and all underwent neurosurgery }\end{array}$ & $\begin{array}{l}\text { The use of rfVIla lowered the INR into } \\
\text { operable range in all patients }\end{array}$ & Low \\
\hline $\begin{array}{l}\text { Sorensen et al. } \\
2003\end{array}$ & Retrospective & $\begin{array}{l}6 \text { patients with } \\
\text { WAICH }\end{array}$ & $\begin{array}{l}\text { All received vitamin } \mathrm{K} \text {, three received FFP. } \\
\text { INR still }>1.5 \mathrm{so} 10-40 \mathrm{\mu g} / \mathrm{kg} \text { rfVlla given to } \\
\text { each patient. All underwent NSGY }\end{array}$ & $\begin{array}{l}\text { All INRs were equal to or }<1.5 \text { within } 10 \\
\text { min of rfVlla being given and allowed for } \\
\text { safe neurosurgical procedure }\end{array}$ & $\begin{array}{l}\text { Very } \\
\text { low }\end{array}$ \\
\hline $\begin{array}{l}\text { Freeman et al. } \\
2004\end{array}$ & Retrospective & $\begin{array}{l}7 \text { patients with } \\
\text { symptomatic } \\
\text { non-traumatic } \\
\text { WAICH }\end{array}$ & $\begin{array}{l}\text { Treated with } 15-90 \mu \mathrm{g} / \mathrm{kg} \text { of rfVlla. Vitamin } \\
\mathrm{K} \text { given to all patients as well except for } \\
\text { one who died prior. All patients but one } \\
\text { also received FFP. Two underwent } \\
\text { neurosurgical procedures }\end{array}$ & $\begin{array}{l}\text { IV bolus rfVlla rapidly lowered the INR to } \\
\text { normalized levels }\end{array}$ & $\begin{array}{l}\text { Very } \\
\text { low }\end{array}$ \\
\hline $\begin{array}{l}\text { Brody et al. } \\
2005\end{array}$ & Retrospective & $\begin{array}{l}28 \text { patients with } \\
\text { WAICH with INR } \\
>1.3\end{array}$ & $\begin{array}{l}15 \text { patients received } 10 \mathrm{mg} \text { IV or } \\
\text { subcutaneously vitamin } \mathrm{K} \text { and FFP. } 12 \\
\text { patients received vitamin } \mathrm{K} \text {, FFP, and rfVlla } \\
\text { as well }\end{array}$ & $\begin{array}{l}\text { Median time from presentation to INR }<1.3 \\
\text { was } 8.8 \mathrm{~h} \text { in the rfVlla group and } 32 \mathrm{~h} \text { in } \\
\text { the FFP group. Significantly lower. One } \\
\text { patient with ESRD developed DIC after } \\
\text { three doses of rfVlla. One patient in the FFP } \\
\text { group developed pulmonary edema }\end{array}$ & Low \\
\hline $\begin{array}{l}\text { Nishijima et al. } \\
2010\end{array}$ & Retrospective & $\begin{array}{l}40 \text { patients with } \\
\text { traumatic } \\
\text { WAICH and INR } \\
1.3 \text { or greater }\end{array}$ & $\begin{array}{l}20 \text { patients received rfVIlla and } 20 \text { did not. } \\
\text { In both groups some patients received } \\
\text { pRBCs, FFP, and vitamin K. Patient } \\
\text { characteristics were similar in both groups }\end{array}$ & $\begin{array}{l}\text { No difference in mortality. } 7 \text { patients died } \\
\text { in each group. There were } 4 / 20 \text { thrombotic } \\
\text { complications in the rfVlla group and } 1 / 20 \\
\text { in the control. This was not statistically } \\
\text { significant. Time to INR normalization was } \\
\text { faster in the rfVlla cohort mean }=4.8 \mathrm{~h} \\
\text { than in the standard cohort mean }=17.5 \mathrm{~h}\end{array}$ & Low \\
\hline
\end{tabular}

Twelve patients received vitamin $\mathrm{K}$, FFP, and rfVIIa as well. Median time from presentation to INR $<1.3$ was significantly lower $(p=0.016)$ in the rfVIIa group $(8.8$ h) compared with the FFP group $(32 \mathrm{~h})$. One patient with ESRD developed DIC after three doses of rfVIIa. One patient in the FFP group developed pulmonary edema [31].

Nishijima et al. retrospectively analyzed 40 patients with WAICH including 20 who received rfVIIa. They found no difference in mortality. Seven patients died in each group. Four of the 20 thrombotic complications occurred in the rfVIIa group and in the control group $(p>0.05)$. Time to normalization of INR was significantly faster $(p<0.001)$ in the rfVIIa cohort (mean = $4.8 \mathrm{~h}$ ) versus the standard cohort (mean $=17.5 \mathrm{~h}$ ) [32].

In conclusion, recombinant factor VIIa appears to rapidly reverse warfarin's effects on INR. This is not an FDA-approved use. This potential rapid reversal benefit must be weighed against the reported 5\% risk of a thromboembolic event.

\section{Is vitamin $\mathrm{K}$ safe and effective and how should it be given?}

Vitamin $\mathrm{K}$ is a necessary component within the liver in order to help carboxylate factors II, VII, IX, and X to their active forms. When warfarin is given, it blocks the reductase that converts oxidized vitamin $\mathrm{K}$ back to vitamin $K$ for reuse [4]. A vitamin $K$ shortage within the liver creates a coagulation cascade deficit. Vitamin K replacement in patients on warfarin can be administered by oral, SQ, or IV route. Oral and SQ routes have variable times to onset and slower absorption rates. Intravenous dosing is recommended in those patients with $\mathrm{ICH}$. Dosages of $10 \mathrm{mg}$ given by slow IV infusion over $30 \mathrm{~min}$ has been recommended [11]. The time to onset is at least 2-6 $\mathrm{h}$ and often more than $24 \mathrm{~h}$ are needed to achieve effective response [4]. Other factor replacement must be given in the interim as well. The incidence of anaphylactic reaction to IV vitamin $\mathrm{K}$ is exceedingly rare with a reported rate of 3 out of 10,000 doses [4]. Many of the reported anaphylaxis episodes occurred with older vitamin $\mathrm{K}$ formulations containing polyethoxylated castor oil, while the modern micelle formulation is thought to have a lower risk of anaphylactoid reactivity [33]. A 2001 review of anaphylactoid reactions associated with vitamin $\mathrm{K}$ reported 23 (3 fatal) case reports and 132 FDA-reported adverse drug events from IV vitamin K, 32 individuals following intramuscular administration, 13 patients following SQ vitamin $\mathrm{K}$, and 7 individuals following oral vitamin $\mathrm{K}$ [34]. In conclusion, 5-10 mg of vitamin $\mathrm{K}$ should be given slowly by IV when a patient presents with WAICH.

\section{What is the risk of thrombosis after warfarin reversal?}

Patients who take warfarin for atrial fibrillation, pulmonary embolus, deep vein thrombosis, or mechanical heart valves are at risk for thrombotic or embolic risk when their anticoagulation is reversed. Physicians need to 
consider this risk when deciding to reverse the anticoagulation. Most reviews and studies view it as an acceptable risk for reversal in the setting of warfarin ICH [7]. Phan et al. showed that discontinuation of warfarin therapy for 1 to 2 weeks in patients with a high embolic risk is relatively safe [35]. The risk for ischemic stroke after discontinuation of warfarin therapy within 30 days was $3 \%$ for metallic valves, $3 \%$ with atrial fibrillation, and 5\% in those with recurrent TIA or minor stroke [35]. Once warfarin is restarted, early recurrence of $\mathrm{ICH}$ is exceedingly uncommon [35]. In conclusion, treating physicians should correct the INR no matter the reason the patient is on anticoagulation. The risk of not treating the $\mathrm{ICH}$ and lowering the INR generally outweighs the risk of thrombosis in the acute setting.

\section{Does rapid correction of anticoagulation improve patient mortality?}

Numerous small studies (Table 4) have reported that the warfarin reversal agents result in more rapid INR normalization and decreased intracranial hematoma expansion [36-40]. The medical literature's reporting of these reversal agents' impact on patient survival is limited to relatively small, primarily retrospective, studies that have investigated whether treatment with a single agent, combination therapy of FFP, vitamin K, PCC, or no reversal therapy affects patient mortality (Table 5) [41-43]. Berwaerts et al. studied 68 patients with WAICH and 126 not on warfarin with ICH between 1993-1999 [41]. The treatment of the 68 patients on warfarin consisted of the following: 19 received only vitamin $\mathrm{K}, 11$ vitamin $\mathrm{K}$ and FFP, 5 FFP alone, 3 vitamin $\mathrm{K}$ and FFP and factor IX, 2 vitamin $\mathrm{K}$ and factor IX, 2 factor IX alone, and 26 received no therapy and were treated with an "expectant attitude." Overall the patients in the study who were not on warfarin had an inpatient mortality of $18 \%$ versus $38 \%$ of those on warfarin [41]. The authors reported no difference in mortality among patients with WAICH who had been reversed with any combination or had not been reversed at all. This method of retrospectively assessing treatment effect is confounded by a great number of treatment arms and small number of patients.

Sjoblom et al. performed a similar study in 2001, retrospectively reviewing charts of 136 patients with WAICH between 1993-1996, who all received some form of reversal [20]. Either single therapy or combinations of vitamin K, factor IX, FFP, or no therapy was administered. There was no evidence that any treatment strategy was superior to the other [20]. Huttner et al. looked at 55 patients with WAICH and compared vitamin K, PCC, and FFP alone or in some combination. They found the incidence and extent of hematoma growth were significantly lower in the PCC-treated group [42]. If the INR was normalized within $2 \mathrm{~h}$, then the influences of FFP and PCC on hematoma growth were similar [42].

In conclusion, multiple small retrospective studies with many treatment arms did not find any difference in one treatment over another or no treatment at all in correcting the INR of those patients with WAICH $[20,21,41,42]$. However, these may very well reflect a type II error given their underpowered sample sizes. A large well-designed prospective study is still needed to determine whether rapid correction of anticoagulation is effective at improving patient-oriented outcomes (i.e.,

Table 4 Studies investigating multiple treatment options for anticoagulation reversal in warfarin-associated intracranial hemorrhage

\begin{tabular}{|c|c|c|c|c|c|}
\hline Author & Study type & Patient population & Intervention & Result & $\begin{array}{l}\text { Grade } \\
{[14]}\end{array}$ \\
\hline $\begin{array}{l}\text { Rabinstein } \\
\text { and Wijdicks } \\
2007\end{array}$ & Retrospective & $\begin{array}{l}13 \text { patients with } \\
\text { spontaneous WAICH }\end{array}$ & $\begin{array}{l}\text { Vitamin K and FFP in "doses } \\
\text { deemed appropriate for each case." } \\
\text { Neurosurgical intervention once } \\
\text { INR }<1.4\end{array}$ & $\begin{array}{l}\text { Median time to reversal } 6.5 \mathrm{~h}(\mathrm{INR}<1.4) \text {. } \\
\text { Recovery in } 65 \% \text { of those patients who fully } \\
\text { awoke within } 36 \mathrm{~h} \text { after evacuation }\end{array}$ & Low \\
\hline $\begin{array}{l}\text { Yasaka et al. } \\
2005\end{array}$ & Prospective & $\begin{array}{l}35 \text { patients with } \\
\text { WAICH }\end{array}$ & $\begin{array}{l}\text { Varying doses of PCC }(200-1,500 \\
\text { IU) were given to see what the } \\
\text { optimal dose was for INR } \\
\text { correction }\end{array}$ & $\begin{array}{l}200 \mathrm{IU} \text { did not decrease } 50 \% \text { of the patients } \\
\text { below } 2.0 \mathrm{INR} \text {. } 500 \mathrm{IU} \text { decreased the INR to }< \\
1.5 \text { in } 96 \% \text { of patients with initial INR }<5.0 \text {. All } \\
\text { patients treated with } 1,000 \mathrm{IU}-1,500 \mathrm{IU} \text { had INR } \\
\text { decrease to }<1.3\end{array}$ & Low \\
\hline Preston 2002 & Prospective & $\begin{array}{l}10 \text { patients with } \\
\text { WAICH }\end{array}$ & $\begin{array}{l}\text { PCC dose range } 25-50 \mu \mathrm{g} / \mathrm{kg} \text { was } \\
\text { used in each patient as reversal as } \\
\text { well as vitamin K 2-5 mg IV }\end{array}$ & $\begin{array}{l}\text { Median INR was } 3.98 \text { prior to treatment and } 20 \\
\text { min after treatment }<1.9 \text { with almost all }<1.3\end{array}$ & Low \\
\hline $\begin{array}{l}\text { Nitu et al. } \\
1998\end{array}$ & Retrospective & $\begin{array}{l}1 \text { patient with WAICH; } \\
17 \text { patients on } \\
\text { warfarin with other } \\
\text { bleeding }\end{array}$ & $\begin{array}{l}\text { Factor IX and factor VII concentrate } \\
\text { given to patients }\end{array}$ & $\begin{array}{l}\text { INR in the patient with } \mathrm{ICH} \text { went from } 5.9 \text { to } \\
\text { post-treatment } 1.8 \text { within } 15 \mathrm{~min}\end{array}$ & Low \\
\hline $\begin{array}{l}\text { Lee et al. } \\
2006\end{array}$ & Retrospective & $\begin{array}{l}45 \text { patients with } \\
\text { WAICH }\end{array}$ & $\begin{array}{l}\text { Varying doses of FFP and vitamin } \mathrm{K} \\
\text { were given for reversal }\end{array}$ & $\begin{array}{l}\text { The median time for door to INR normalization } \\
\text { was } 30 \text { h ( } 14 \text { to } 49.5) \text {, with } 4 \text { patients' } \\
\text { hematomas enlarging after INR normalization }\end{array}$ & Low \\
\hline
\end{tabular}


Table 5 Studies investigating the available anticoagulation reversal agents' impact on patient survival

\begin{tabular}{|c|c|c|c|c|c|}
\hline Author & Study type & $\begin{array}{l}\text { Patient } \\
\text { population }\end{array}$ & Intervention & Result & $\begin{array}{l}\text { Grade } \\
{[14]}\end{array}$ \\
\hline $\begin{array}{l}\text { Berwaerts et al. } \\
2000\end{array}$ & Retrospective & $\begin{array}{l}68 \text { patients with } \\
\text { WAICH }\end{array}$ & $\begin{array}{l}19 \text { patients received vitamin } \mathrm{K} \text { only, } 11 \\
\text { vitamin } \mathrm{K}+\mathrm{FFP}, 5 \mathrm{FFP}, 3 \text { vitamin } \mathrm{K}+\mathrm{FFP} \\
+ \text { factor IX, } 2 \text { vitamin } \mathrm{K}+\text { factor IX, } 2 \\
\text { factor IX, and } 26 \text { were treated with an } \\
\text { "expectant attitude" }\end{array}$ & $\begin{array}{l}\text { No significant difference in mortality rate } \\
\text { among patients who had been reversed } \\
\text { with any combination of reversal agents } \\
\text { or had not been reversed }\end{array}$ & Low \\
\hline $\begin{array}{l}\text { Sjoblom et al. } \\
2001\end{array}$ & Retrospective & $\begin{array}{l}136 \text { patients with } \\
\text { WAICH who } \\
\text { received some } \\
\text { form of reversal }\end{array}$ & $\begin{array}{l}\text { Either single therapy or combinations of } \\
\text { vitamin K, factor IX, FFP, or no therapy } \\
\text { was administered }\end{array}$ & $\begin{array}{l}\text { No evidence that any treatment strategy } \\
\text { was superior to the others }\end{array}$ & Moderate \\
\hline $\begin{array}{l}\text { Huttner et al. } \\
2006\end{array}$ & Retrospective & $\begin{array}{l}55 \text { patients with } \\
\text { WAICH }\end{array}$ & $\begin{array}{l}\text { Compared vitamin K, PCC, and FFP alone } \\
\text { or in some combination }\end{array}$ & $\begin{array}{l}\text { Incidence and extent of hematoma } \\
\text { growth were significantly lower in the } \\
\text { PCC-treated group. If the INR was } \\
\text { normalized within } 2 \mathrm{~h} \text { then FFP and PCC } \\
\text { influence on hematoma growth were } \\
\text { similar }\end{array}$ & Low \\
\hline $\begin{array}{l}\text { Goldstein et al. } \\
2006\end{array}$ & Retrospective & $\begin{array}{l}69 \text { patients with } \\
\text { non traumatic } \\
\text { WAICH with INR } \\
>1.4\end{array}$ & $\begin{array}{l}\text { Patients received no therapy, FFP, vitamin } \\
\mathrm{K} \text {, or combination }\end{array}$ & $\begin{array}{l}\text { Patients whose INR was successfully } \\
\text { reversed within } 24 \text { h had a shorter time } \\
\text { from diagnosis to first dose of FFP ( } 90 \text { vs. } \\
210 \text { min). Shorter time to vitamin K as } \\
\text { well predicted INR correction. Every } 30 \\
\text { min of delay in the first dose of FFP was } \\
\text { associated with } 20 \% \text { decreased odds of } \\
\text { INR reversal within } 24 \text { h. No ED } \\
\text { intervention was associated with } \\
\text { improved clinical outcome }\end{array}$ & Moderate \\
\hline $\begin{array}{l}\text { Yasaka et al. } \\
2003\end{array}$ & Prospective & $\begin{array}{l}15 \text { patients with } \\
\text { WAICH }\end{array}$ & $\begin{array}{l}9 \text { PCCs with vitamin K } 10-20 \mathrm{mg} \text { IV, } 2 \\
\text { PCCs alone or } 4 \text { with vitamin K } 10-20 \mathrm{mg} \\
\text { IV alone were administered based on } \\
\text { decision of treating MD }\end{array}$ & $\begin{array}{l}\text { Vitamin } \mathrm{K} \text { lowered the INR after } 12-24 \mathrm{~h} \\
\text { to normalized range. PCC with or } \\
\text { without vitamin } \mathrm{K} \text { was more effective at } \\
\text { rapidly correcting the increased INR. PCC } \\
\text { without vitamin K administration led to a } \\
\text { recurrent increase in INR after } 12-24 \mathrm{~h}\end{array}$ & Low \\
\hline
\end{tabular}

functional neurologic recovery) and an appropriate utilization of healthcare resources.

\section{Conclusions}

Emergency medicine physicians will see increasing numbers of patients on warfarin as the population ages. Physicians must know how to treat patients who present with warfarin-associated intracranial hemorrhage. PCC appears to normalize the INR faster than FFP. Vitamin $K$ is generally safe and should be administered by slow IV infusion in all patients who present with WAICH. rfVIIa has not yet been approved for use in WAICH, but has shown promising results in fast normalization of INR in a small subset of patients, but at the cost of a $5 \%$ thromboembolic event rate. Despite the multiple treatment options to correct anticoagulation, studies have yet to demonstrate improved patient survival with any particular treatment strategy.

\section{Funding sources}

No industry financial support or compensation was received for conducting this study. The study was entirely funded by the Vanderbilt University Medical Center Department of Emergency Medicine Research Division. Dr. Barrett is supported in part by NIH grant
K23 HL102069 from the National Heart, Lung, and Blood Institute.

\section{Disclosure}

Dr. Cotton currently serves as an adjudicator for ongoing research sponsored by CSL Behring (makers of prothrombin complex concentrate).

\section{Author details \\ ${ }^{1}$ Department of Emergency Medicine, Vanderbilt University Medical Center, Nashville, TN, USA ${ }^{2}$ Eskind Biomedical Library, Vanderbilt University School of Medicine, Nashville, TN, USA ${ }^{3}$ Department of Surgery, Brooke Army Medical Center, Fort Sam Houston, TX, USA ${ }^{4}$ Department of Surgery, Center for Translational Injury Research/The University of Texas Medical School, Houston, TX, USA}

\section{Authors' contributions}

$\mathrm{TB}$ and $\mathrm{BC}$ conceived the study idea. $\mathrm{TB}, \mathrm{BB}, \mathrm{BC}, \mathrm{TN}$, and $J \mathrm{~L}$ developed the study design and objectives. $J$ queried numerous medical literature databases on multiple occasions to retrieve the most current literature on the study topic. BB, TN and JL performed the initial screening of potentially eligible abstracts. TB adjudicated disagreements in potential article eligibility. $B B$ wrote the initial draft of the paper. $B B, T N, J L, T N, B C$, and $T B$ directly participated in the multiple revisions of the intellectual content of the manuscript. All authors read and approved the final manuscript

\section{Competing interests}

The other authors declare that they have no competing interests.

Received: 8 March 2011 Accepted: 8 July 2011 Published: 8 July 2011 


\section{References}

1. Wysowski DK, Nourjah P, Swartz L: Bleeding complications with warfarin use. Arch Intern Med 2007, 167:1414-1419.

2. Go AS, Hylek EM, Phillips KA, et al: Prevalence of diagnosed atrial fibrillation in adults: national implications for rhythm management and stroke prevention: the AnTicoagulation and Risk Factors In Atrial Fibrillation (ATRIA) Study. JAMA 2001, 285:2370-2375.

3. Jagoda AS, Bazarian JJ, Bruns JJ Jr, et al: Clinical policy: Neuroimaging and decision making in adult mild traumatic brain injury in the acute setting. Ann Emerg Med 2008, 52:714-48.

4. Steiner T, Rosand J, Diringer M: Intracerebral hemorrhage associated with oral anticoagulant therapy. Stroke 2006, 37:256-262.

5. Thompson KM, Gerlach SY, Jorn KS, et al: Advances in the care of patients with intracerebral hemorrhage. Mayo Clin Proc 2007, 82:987-990.

6. Appelboam R, Thomas EO: Warfarin and intracranial haemorrhage. Blood Rev 2009, 23:1-9.

7. Butler AC, Tait RC: Management of oral anticoagulant-induced intracranial haemorrhage. Blood Rev 1998, 12:35-44.

8. Asdaghi N, Manawadu D, Butcher K: Therapeutic management of acute intracerebral haemorrhage. Expert Opin Pharmacother 2007, 8:3097-3116.

9. Beyth RJ: Hemorrhagic Complications of oral anticoagulant therapy. Clin Geriatr Med 2001, 17:49-56.

10. Towfighi A, Greenberg S, Rosand J: Treatment and prevention of primary intracerebral hemorrhage. Semin Neurol 2005, 25:445-452.

11. Freeman WD, Aguilar MI: Management of warfarin-related intracerebral hemorrhage. Expert Rev Neurotherapeutics 2008, 8:271-290.

12. Hart RG, Aguilar Ml: Anticoagulation in atrial fibrillation: selected controversies including optimal anticoagulation intensity, treatment of intracerebral hemorrhage. J Thromb Thrombolysis 2008, 25:26-32.

13. Hanley JP: Warfarin Reversal. J Clin Pathol 2004, 57:1132-1139.

14. Guyatt, et al: GRADE guidelines: A new series of articles in the Journal of Clinical Epidemiology. J Clin Epidemiol 2011, 64:380-2.

15. Bartal C, Freedman J, Bowman K, et al: Coagulopathic patients with traumatic intracranial bleeding: defining the role of recombinant factor VIla. J Trauma 2007, 63:725-732.

16. Baldi $\mathrm{G}$, Altomonte $\mathrm{F}$, Altomonte $\mathrm{M}$, et al: Intracranial haemorrhage in patients on antithrombotics: clinical presentation and determinants of outcome in a prospective multicentric study in Italian emergency departments. Cerebrovasc Dis 2006, 22:286-293.

17. Kalina $M$, Tinkoff $G, G$ badebo $A$, et al: $A$ protocol for the rapid normalization of inr in trauma patients with intracranial hemorrhage on prescribed warfarin therapy. Am Surg 2008, 74:858-61.

18. Ivascu FA, Janczyk RJ, Junn FS, et al: Treatment of trauma patients with intracranial hemorrhage on preinjury Warfarin. J Trauma 2006, 61:318-321.

19. Aguilar MI, Hart RG, Kase CS, et al: Treatment of warfarin-associated intracerebral hemorrhage: literature review and expert opinion. Mayo Clin Proc 2007, 82:82-92.

20. Sjoblom L, Hardemark HG, Lindgren A, et al: Management and prognostic features of intracerebral hemorrhage during anticoagulant therapy (a Swedish multicenter study). Stroke 2001, 32:2567-2574.

21. Goldstein JN, Thomas SH, Frontiero $V$, et al: Timing of fresh frozen plasma administration and rapid correction of coagulopathy in warfarin-related intracerebral hemorrhage. Stroke 2006, 37:151-155.

22. Boulis NM, Bobek MP, Schmaier A, et al: Use of factor IX complex in warfarin-related intracranial hemorrhage. Neurosurgery 1999, 45:1113-1118.

23. Makris M, Greaves M, Phillips WS, et al: Emergency oral anticoagulant reversal: the relative efficacy of infusions of fresh frozen plasma and clotting factor concentrate on correction of the coagulopathy. Throb Haemostasis 1997, 77:477-480.

24. Fredriksson K, Norrving B, Stromblad LG: Emergency reversal of anticoagulation after intracranial hemorrhage. Stroke 1992, 23:972-977.

25. Cartmill M, Dolan G, Byrne $J$, et al: Prothrombin complex concentrate for oral anticoagulant reversal in neurosurgical emergencies. $\mathrm{Br} J$ Neurosurg 2000, 14:458-461.

26. Siddiq F, Jalil A, McDaniel $C$, et al: Effectiveness of factor IX complex concentrate in reversing warfarin associated coagulopathy for intracerebral hemorrhage. Neurocrit Care 2008, 8:36-41.

27. Fewel ME, Park P: The emerging role of recombinant-activated factor VII in neurocritical care. Neurocrit Care 2004, 1:19-30.

28. Levi M, Levy JH, Andersen HF, Truloff D: Safety of recombinant activated factor vii in randomized clinical trials. N Engl J Med 2010, 363:1791-1800.
29. Sorensen B, Johansen P, Nielsen G, et al: Reversal of the international normalized ratio with recombinant activated factor VII in central nervous system bleeding during warfarin thromboprophylaxis: clinical and biochemical aspects. Blood Coagul Fibrinolysis 2003, 14:469-477.

30. Freeman WD, Brott TG, Barrett KM, et al: Recombinant factor VIla for rapid reversal of warfarin anticoagulation in acute intracranial hemorrhage. Mayo Clin Proc 2004, 79:1495-1500.

31. Brody DL, Aiyagaria V, Shackleford AM, et al: Use of recombinant factor VIla in patients with warfarin-associated intracranial hemorrhage. Neurocritical Care 2005, 2:263-267.

32. Nishijima DK, Dager WE, Schrot RJ, et al: The efficacy of factor VIla in emergency department patients with warfarin use and traumatic intracranial hemorrhage. Acad Emerg Med 2010, 17:244-251.

33. Makris $M$, van Veen JJ, Maclean R: Warfarin anticoagulation reversal: management of the asymptomatic and bleeding patient. J Thromb Thrombolysis 2010, 29:171-81.

34. Fiore LD, Scola MA, Cantillon CE, et al: Anaphylactoid reactions to vitamin K. J Thromb Thrombolysis 2001, 11:175-183.

35. Phan TG, Koh M, Wijdicks EF: Safety of discontinuation of anticoagulation in patients with intracranial hemorrhage at high thromboembolic risk. Arch Neurol 2000, 57:1710-1713.

36. Rabinstein AA, Wijdicks EM: Determinants of outcome in anticoagulationassociated cerebral hematoma requiring emergency evacuation. Arch Neurology 2007, 64:203-206.

37. Yasaka M, Sakata T, Naritomi H, et al: Optimal dose of prothrombin complex concentrate for acute reversal of oral anticoagulation. Thromb Res 2005, 115:455-459.

38. Preston FE, Laidlaw ST, Sampson B, et al: Rapid reversal of oral anticoagulation with warfarin by a prothrombin complex concentrate (Beriplex): efficacy and safety in 42 patients. Br J Haematol 2002, 116:619-624.

39. Nitu IC, Perry DJ, Lee CA: Clinical experiences with the use of clotting factor concentrates in oral anticoagulation reversal. Clin Lab Haem 1998 20:363-367.

40. Lee SB, Manno EM, Layton KF, et al: Progression of warfarin-associated intracerebral hemorrhage after INR normalization with FFP. Neurology 2006, 67:1272-1274.

41. Berwaerts J, Robb OJ, Dykhuizen RS, et al: Course, management and outcome of oral-anticoagulant-related intracranial haemorrhages. Scott Med J 2000, 45:105-109.

42. Huttner HB, Schellinger PD, Hartmann M, et al: Hematoma growth and outcome in treated neurocritical care patients with intracerebral hemorrhage related to oral anticoagulant therapy. Stroke 2006, 37:1465-1470.

43. Yasaka M, Sakata T, Minematsu K, et al: Correction of INR by prothrombin complex concentrate and vitamin $\mathrm{K}$ in patients with warfarin related hemorrhagic complication. Thromb Res 2003, 108:25-30.

doi:10.1186/1865-1380-4-40

Cite this article as: Bechtel et al:: Treatments for reversing warfarin anticoagulation in patients with acute intracranial hemorrhage: a structured literature review. International Journal of Emergency Medicine 2011 4:40.

\section{Submit your manuscript to a SpringerOpen ${ }^{\circ}$ journal and benefit from:}

- Convenient online submission

- Rigorous peer review

- Immediate publication on acceptance

- Open access: articles freely available online

- High visibility within the field

- Retaining the copyright to your article

Submit your next manuscript at $>$ springeropen.com 